\title{
Sources of Stress, Coping Strategies with Stress and Job Satisfaction of Teachers in Art Schools
}

\author{
Melita Ivanković \\ Ministry of Science and Education of the Republic of Croatia
}

\section{Abstract}

Researches on teachers' stress have shown that stress is an important factor upon which educational process depends (Kyriacou, 2001). In this article teachers in art schools in the Republic of Croatia $(N=148)$ were studied. The aim of this article is to determine which are the sources of stress in teachers at elementary music and dancing schools. Besides, one of the problems is to observe ways of teachers' coping with stress as well as correlation with job satisfaction of teachers in art schools. Teachers in art schools are mostly satisfied with their work despite the fact that it is a very stressful profession. Sources of stress of teachers in art schools are to some extent similar to sources of stress of the past researches on teachers. Teachers mostly use coping strategies with stress directed to the problem such as problem solving. A positive correlation of positive coping strategies with stress and job satisfaction was also noticed and the highest correlation shows usage of positive coping strategies with stress. A negative correlation of strategies directed to emotions and job satisfaction such as evasion of coping with problems was also observed. The results refer to particularities of art education and encourage for further researches.

Key words: coping strategies; job satisfaction; sources of stress; teachers in art fields

\section{Introduction}

Authors Lazarus and Folkman (2004) define stress as a relationship between a person and her/his environment and notice that it represents a relationship when a person evaluates that demands of the environment are too demanding and endanger her/his well-being. Grant (2007) defines stress at work when people cannot satisfy demands 
of the environment which is very often in correlation with the term of work burnout, consequences of which affect work capability of the teacher and work environment.

Researches on teachers' stress have shown that work stress in teachers is one of the factors influencing the quality of educational process as well as that it is correlated with teachers' job satisfaction (Kyriacou, 2001). Teacher's occupation is very demanding and stressful which is shown by studies of numerous authors (Montgomery \& Rupp, 2005; Pillay et al., 2005; Sklaalvik \& Sklaalvik, 2015; Zurlo et al., 2007) and negatively affects psychophysical health which causes emotional exhaustion and burnout.

Among stressors that are especially emphasized in teachers are: pupils' behaviour, relationships with colleagues and parents, professional acknowledgements and work conditions (Brkić \& Rijavec, 2011; Miljković \& Rijavec, 2007). Authors Sklaalvik and Sklaalvik (2015) consider that stress at work is connected with factors depending upon schools and that are also connected with teachers' motivation, well-being and quality of teachers' education. According to the same authors, sources of stress in teachers are too encompassing pedagogical documentation, administrative tasks and preparation for classes. They also noticed that younger teachers are more exposed to stress and that they prepared more for classes, whereas middle-age and elderly teachers were more frequently absent from work.

Teachers in elementary schools were more exposed to stress than teachers in high schools. Gender proved as an essential variable and women experience higher level of stress in comparison to men (Nasser-Abu Alhija, 2015).

Kyriacou (2001) states that teachers' stress is a special kind of professional stress which implicitly includes unpleasant emotions such as irritability, anger and depression.

According to Gordon (2001) there are three categories of stress sources in music teachers and these are: a) behaviour and attitudes of pupils, colleagues, parents and administrative personnel at school; b) complexity of programmes that negatively affect implementation and c) inappropriate preparation for music teaching.

Key factors in successful coping of teachers with stressful situations are individual ways of stress coping of every teacher, whereby teachers' interpretations of a particular stressful situation is to be especially emphasized (e.g. Jepson \& Forrest, 2006). Work conditions proved as an important factor in perception of various stressors and strategies of coping with stress (Nasser-Abu Alhija, 2015).

Montgomery and Rubb (2005) suggested a model of key constructive parts correlated with stress and teachers' facing and their mutual relationship. Their model presumes that every teacher experiences and assesses external stressful situations such as professional life and personal teachers' life as well as external and internal aspects of a teacher's life. Professional teacher's life consists of pupils, colleagues, administration, work and school envirnoment and personal teacher's life is made up of family relationships and financial problems. After stress assessment, a teacher includes active or passive coping strategies with stress.

According to the theory of stress and its facing made by Lazarus and his colleagues (1984), ways of facing stressful situations are divided into two ways of facing and these 
are: facing directed to emotions and facing direted to the problem. Coping strategy directed towards the problem is a way of facing that includes strategies aimed at assessment, choice and facing stressful situations or modifications of sources of stress. Coping strategy directed to emotions is aimed at regulation of emotional conditions, whereby coping strategies such as going away, evasion, expressing emotions towards others and search for emotional support from others.

According to Kyiracou (2001), teachers mostly face stress by avoiding conflicts, they use different forms of relaxation, solve problems and discuss about the problem with others.

Researches revealed that choice of coping strategy with stress in teachers modifies effects of professional stress upon their well-being, whereby inefficient coping strategies with stress may with time result in work burnout (Borg \& Riding, 1991; Chan, 1998).

Usage of coping strategies directed to the problem such as asking for support from colleagues and school management or active problem solving affect stress relief positively (Betoret, 2009; Brkić \& Rijavec, 2011) by means of which probability of work burnout is indirectly reduced. People facing stress directed to the problem contribute to positive cognitive assessments that are manifested by positive emotions (Folkman \& Lazarus, 1990).

Some researches indicated that the concept of work dedication such as positive attitudes towards work and pupils is more efficient than prevention of stressful events (Maslach, 2003). Also, research by Evers et al. (2002) confirmed a positive correlation between teacher's competence and stress.

Problems with discipline in some studies proved to be connected with teacher's burnout (Kokkinos, 2007; Skaalvik \& Skaalvik, 2011). Positive social climate at school including social support and positive relationships with colleagues, parents and pupils is negatively correlated with teacher's burnout (Hakanen et al., 2006). In the studies by Skaalvika and Skaalvika $(2009 ; 2014)$ teacher's autonomy is positively correlated with job satisfaction and work dedication and negatively correlated with work stress.

Locke (1976, p. 1304) defines job satisfaction as pleasant or positive emotional state which is the result of work achievements or achievement supports. Koludrović et al. (2008) consider that the key factor of work dedication is job satisfaction as it influences teacher's motivation for work and personal engagement within school.

On the basis of Herzberg's theory, intrinsic and extrinsic motivation affect job satisfaction (Bahtijarević-Šiber, 1999). Relationship with pupils also proved to be the most important source of satisafaction and motivation in the teacher's profession (Klassen et al., 2012). Job satisfaction is considerably correlated with intrinsic motivation (Dinham \& Scott, 1998) for teaching and teachers' source of job satisfaction is work with children (Sklaalvik \& Sklaalvik, 2015).

Despite the stated cognitions that teachers are exposed to various distressors, researches on teachers' job satisfaction confirm that teachers are satisfied with their work (Hakanen et al., 2006; Timms et al., 2007; Vidić, 2009). Sources of job satisfaction 
in music teachers are factors such as work autonomy, feedback information and social support of colleagues (Bakker, 2005).

Despite job satisfaction, one of the factors of teachers' dissatisfaction is professional status (Kadum et al., 2007; Vidić 2009).

\section{Methods}

\section{Aim and problems of the research}

The main aim of the research was to check perception of the main sources of stress, coping strategies with stress and job satisfaction and to determine correlations among variables.

In connection with this, five research problems were set:

1 To examine the most important sources of stress of teachers in music and dancing schools and whether there is a statistically significant difference in sources of stress among teachers in music and dancing schools.

2 To examine which are the most crucial coping strategies with stress of teachers in dancing and music schools and whether there is a statistically significant difference in coping with stress among teachers in music and dancing schools.

3 To examine job satisfaction for teachers in dancing and music schools and whether there is a statistically significant difference in sources of teachers' satisfaction in these two occupations.

4 To check whether there are statistically significant differences in sources of stress, stress facing and job satisfaction depending on the gender of the teacher.

5 To determine the correlation of overall satisfaction and individual sources of stress and coping strategies with stress.

\section{Procedure of the research}

\section{Preliminary research}

Preliminary research for the questionnaire Sources of Stress was conducted first. In the preliminary research the sample encompassed $(\mathrm{N}=93)$ music and dancing teachers in elementary schools in Zagreb. Out of the total number of respondents, 67 of them are teachers in music schools and 26 teachers in dancing schools. The teachers were given a task to write down what they consider sources of work stress and they had to describe them shortly. The obtained sources of stress are grouped into categories according to the meaning and for each category one statement was chosen that described all the statements from the group the best. We obtained all together fifty-eight statements that were included in the main research.

\section{The main research}

In the basic research the sample included $(\mathrm{N}=148)$ music and dancing teachers in elementary schools in the Republic of Croatia, and $83.7 \%$ of them are teachers in music schools and $16.3 \%$ are teachers in dancing schools. From the total sample, $62.8 \%$ are 
women and $37.2 \%$ are men. The research was conducted in elementary music and dancing schools during the session of Teachers' council.

\section{Applied measuring instruments}

The measuring instrument that was applied was: Sources of stress of teachers in music and dancing schools (Ivanković, 2018). The questionnaire measures sources of work stress of teachers in dancing and music schools. The respondents assess what the sources of work stress are by using Likert scale with five degrees (1- I do not agree at all, 5- I agree completely). The questionnaire comprises 48 items connected with sources of teachers' stress.

COPE scale (Scales Inventory Carver, Scheier and Weintrab, 1989) was translated and adapted in the Republic of Croatia (Hudek-Knežević et al.,1999). The questionnaire measures ways of coping with stress in elderly people. The respondents assess the way in which they cope with stress by using Likert's scale made of five degrees ( 1 - I agree completely, 5- I disagree completely). The questionnaire comprises 48 items.

Job satisfaction (Job Descriptive Index - JDI) questionnaire made by Smith et al.(1969) and developed by Gregson (1991), was translated and adapted in the Republic of Croatia (Vidić, 2009). The questionnaire was modified and two items were changed. It consists of five factors (salary, colleagues, superiors, promotion and work). The respondents assess the extent of their work satisfaction on the Likert scale made up of five degrees (1- I completely disagree, 5- I completely agree). The questionnaire consists of 25 items.

\section{Results}

First we conducted a factor analysis for the questionnaire Job satisfaction so as to check factor structure on the sample of respondents. Exploratory factor analysis was used by method of the main components with Varimax rotation.

The questionnaire of Job satisfaction along with the initial solution of the factor analysis with all its 25 statements explained $62.8 \%$ of job satisfaction variance and six factors were extracted. Five factors were similar to the obtained factors as was the case in the authors of the original scale (Gregson, 1990), and one factor consisting of only two statements was not interpretable. Therefore, these two statements were excluded from the original scale („My head-master/head-mistress is tactful; „My job is tiresome") and a new factor analysis was conducted. By means of the new factor analysis with 23 statements, $61.3 \%$ of the variance was explicated and we obtained 5 interpretable factors (along with $\mathrm{KMO}=.746$ and Barlett test $=1443.1 ; \mathrm{df}=253 ; \mathrm{p}<.01$ ). The factors are now also similar to the original questionnaire's and may be called the same names: salary, colleagues, promotion, superiors and work.

Factor Salary comprises five statements, three of which are negative and two are positive. After recoding the negative statements Alpha coefficient of the scale's reliability amounts to 0.86 . All the statements this factor is made up of are a part of 
the statements of the same factor in the original scale. This factor explicates $14.7 \%$ of job satisfaction variance.

Factor Colleagues comprises five statements three of which are negative and two are positive. After recording the negative statements, Alpha coefficient of scale's reliability amounts to 0.81. All the statements which make up the factor Colleagues are a part of statements of the same factor in the original scale. $13.3 \%$ of job satisfaction variance was explained by this factor.

Furthermore, factor Promotions is made up of all together two negative statements ( e.g., In my job you cannot get a promotion and Favourable conditions for promotion are considerably limited in my school) and three positive ones (e.g., There are great chances for promotion at my work, Promotions at my work are based upon capabilities and In my school there are good chances for promotion). By recoding the negative statements we obtained Alpha reliability coefficient of 0.81 . All the statements within the same factor are also found in the original scale of job satisfaction. By means of this factor a total of $12.3 \%$ of job satisfaction variance was explicated.

The fourth obtained factor Superiors consists of four negative statements (e.g., My head-master/head-mistress is short-tempered, My head-master/headmistress is stubborn, It is hard to please my head-master/head-mistress and My head-master/head-mistress is unkind) which after recoding show the reliability of 0.76 and explicate $10.9 \%$ of job satisfaction variance. All the statements are at the same position in the original scale as well.

Finally, the fifth obtained factor called Work comprises four positive statements (e.g., Work gives me the feeling of fulfilment, My work means a challenge to me, Work gives me satisfaction and My work is good). We find out here as well that the mentioned statements are found within the same factor of the original scale. These statements give reliability of 0.73 all together and explicate a total of $10.1 \%$ job satisfaction variance.

In Table 1 factor structure of all obtained factors is shown and in Table 2 descriptive statistics of individual statements and average result on an individual factor. Since all factors are not made up of the same number of statements, average results of individual factors due to comparability of average marks were analyzed.

Based upon the results in Table 2 we observe that the respondents mostly agree with the statements referring to work-fulfilment (e.g., Work gives me a feeling of ful-filment, My work offers me a challenge, Work offers me satisfaction and My work is good). All the statements have a mark of 3.9 or a higher one; however, as some statements are negative, it is clear that agreeing with them does not mean positiveness for the factor made up by this statement. After the change of negative statements and calculation of all factors it is noticed that the respondents achieve the highest result on the factor Superiors $(\mathrm{M}=4.5)$, then Work $(\mathrm{M}=4.1)$, then Colleagues $(\mathrm{M}=3.9)$, then Promotion $(\mathrm{M}=3.6)$ and they are the least satisfied with the factor Salary $(\mathrm{M}=2.7)$. 
Table 1

Factor structure of the scale for measuring Job satisfaction

\begin{tabular}{|c|c|c|c|c|c|}
\hline \multirow{2}{*}{ STATEMENTS } & \multicolumn{5}{|c|}{ FACTORS } \\
\hline & Salary & Colleagues & Promotions & Superiors & Work \\
\hline My salary is too low. & .847 & & & & \\
\hline My salary is bad. & .844 & & & & \\
\hline $\begin{array}{l}\text { My income is less than I } \\
\text { deserve. }\end{array}$ & .824 & & & & \\
\hline I am well-paid. & -.787 & & & & \\
\hline $\begin{array}{l}\text { My salary is sufficient for } \\
\text { normal costs. }\end{array}$ & -.683 & & & & \\
\hline $\begin{array}{l}\text { My colleagues are } \\
\text { intelligent. }\end{array}$ & & -.820 & & & \\
\hline $\begin{array}{l}\text { My colleagues are not hard } \\
\text { working. }\end{array}$ & & .769 & & & \\
\hline My colleagues are boring. & & .746 & & & \\
\hline My colleagues are languid. & & .669 & & & \\
\hline My colleagues are smart. & & -.616 & & & \\
\hline $\begin{array}{l}\text { There are great chances for } \\
\text { promotion in my job. }\end{array}$ & & & .804 & & \\
\hline $\begin{array}{l}\text { In my school there are good } \\
\text { chances for promotion. }\end{array}$ & & & .771 & & \\
\hline $\begin{array}{l}\text { In my job you cannot get a } \\
\text { promotion. }\end{array}$ & & & -.749 & & \\
\hline $\begin{array}{l}\text { Favourable conditions for } \\
\text { promotion are quite limited } \\
\text { in my school. }\end{array}$ & & & -.712 & & \\
\hline $\begin{array}{l}\text { Promotions in my work are } \\
\text { based upon capabilities. }\end{array}$ & & & .449 & & \\
\hline $\begin{array}{l}\text { My head-master/head- } \\
\text { mistress is short tempered. }\end{array}$ & & & & .793 & \\
\hline $\begin{array}{l}\text { My head-master/head- } \\
\text { mistress is stubborn. }\end{array}$ & & & & .768 & \\
\hline $\begin{array}{l}\text { It is hard to please my head- } \\
\text { master/head-mistress. }\end{array}$ & & & & .724 & \\
\hline $\begin{array}{l}\text { My head-master/head- } \\
\text { mistress is unkind. }\end{array}$ & & & & .708 & \\
\hline $\begin{array}{l}\text { Work gives me a feeling of } \\
\text { fufilment. }\end{array}$ & & & & & .781 \\
\hline $\begin{array}{l}\text { My work offers me a } \\
\text { challenge. }\end{array}$ & & & & & .718 \\
\hline Work gives me satisfaction. & & & & & .710 \\
\hline My work is good. & & & & & .646 \\
\hline
\end{tabular}


Table 2

Descriptive statistics of individual statements and the factor* on the scale Job satisfaction

\begin{tabular}{|c|c|c|c|c|}
\hline & M & $\mathrm{C}$ & $\mathrm{D}$ & SD \\
\hline My salary is too low. & 3.7 & 4.0 & 3.0 & 1.00 \\
\hline My salary is bad. & 3.1 & 3.0 & 3.0 & 1.18 \\
\hline My income is less than I deserve. & 3.6 & 3.5 & 3.0 & 1.10 \\
\hline I am well-paid. & 2.6 & 3.0 & 3.0 & 1.03 \\
\hline My salary is sufficient for normal costs. & 3.2 & 3.0 & 4.0 & 1.18 \\
\hline SALARY & 2.7 & 2.8 & 3.0 & 0.89 \\
\hline My colleagues are intelligent. & 3.8 & 4.0 & 4.0 & 0.92 \\
\hline My colleagues are not hard working. & 2.1 & 2.0 & 1.0 & 1.04 \\
\hline My colleagues are boring. & 2.0 & 2.0 & 1.0 & 1.03 \\
\hline My colleagues are languid. & 2.3 & 2.0 & 2.0 & 1.04 \\
\hline My colleagues are smart. & 3.8 & 4.0 & 4.0 & 0.95 \\
\hline COLLEAGUES & 3.9 & 3.8 & 3.8 & 0.75 \\
\hline There are great chances for promotion in my job. & 3.2 & 3.0 & 3.0 & 1.09 \\
\hline In my school there are good chances for promotion. & 3.8 & 4.0 & 4.0 & 1.05 \\
\hline In my job you cannot get a promotion. & 2.1 & 2.0 & 1.0 & 1.16 \\
\hline $\begin{array}{l}\text { Favourable conditions for promotion are quite limited } \\
\text { in my school. }\end{array}$ & 2.3 & 2.0 & 2.0 & 1.12 \\
\hline Promotions in my work are based upon capabilities. & 3.3 & 3.0 & 3.0 & 1.07 \\
\hline PROMOTION & 3.6 & 3.6 & 3.6 & 0.83 \\
\hline My head-master/head-mistress is short tempered. & 1.7 & 1.0 & 1.0 & 0.99 \\
\hline My head-master/head-mistress is stubborn. & 1.6 & 1.0 & 1.0 & 0.85 \\
\hline It is hard to please my head-master/head-mistress. & 1.6 & 1.0 & 1.0 & 0.91 \\
\hline My head-master/head-mistress is unkind. & 1.2 & 1.0 & 1.0 & 0.62 \\
\hline SUPERIORS & 4.5 & 4.5 & 5.0 & 0.65 \\
\hline Work gives me a feeling of fufilment. & 4.0 & 4.0 & 4.0 & 0.92 \\
\hline My work offers me a challenge. & 3.9 & 4.0 & 4.0 & 0.86 \\
\hline Work gives me satisfaction. & 4.3 & 4.0 & 4.0 & 0.71 \\
\hline My work is good. & 4.2 & 4.0 & 4.0 & 0.77 \\
\hline WORK & 4.1 & 4.0 & 4.0 & 0.61 \\
\hline
\end{tabular}

INDEX:

$\mathrm{M}$-arithmetic mean, $\mathrm{C}=$ central value, $\mathrm{D}=$ dominant value; $\mathrm{SD}=$ standard deviation

*average values were calculated for each statement separately in a positive or negative form depending upon the statement, whereas average values on factors were obtained by conversion of all negative statements into positive ones. 
For the results of the questionnaire Sources of stress and Coping strategies with stress in this research, facor analyses with the aim of defining factor structures of the two questionnaires were not calculated because of great number of statements in both questionnaires and with regard to the number of respondents in the research.

Connected with the emphasis of individual stressors, the most pronounced were: work with unmotivated pupils, parents' disrespect, negative social attitude towards educational work of teachers, too much work at the end of school year, simultaneous solving of a couple of urgent tasks (Picture 1).

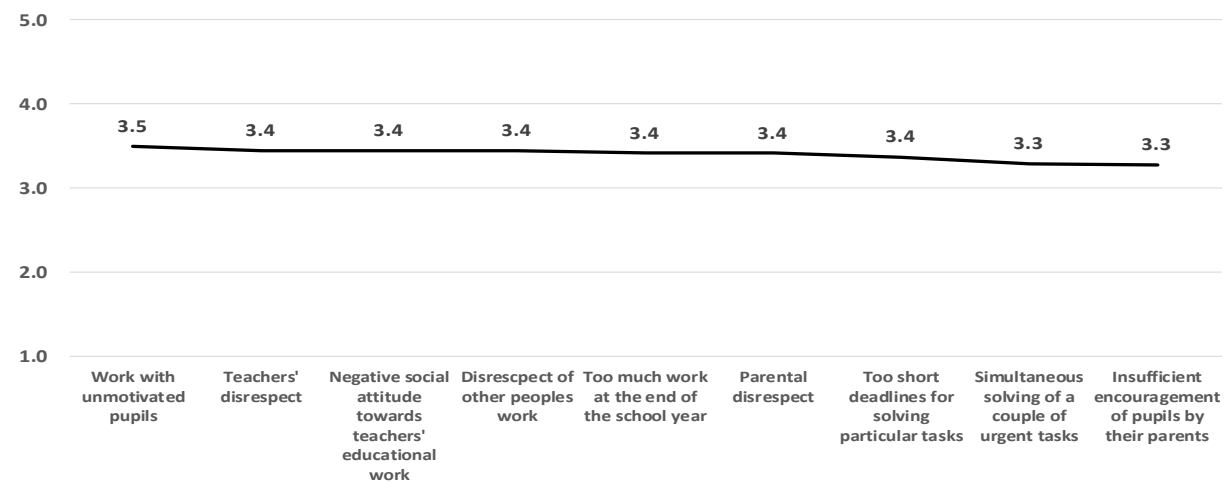

Picture 1 Graphic illustration of sources of stress

Results of the questionnaire Coping strategies with stress show that dancing and music teachers mostly use generally positive coping strategies with stress, whereas they use negative strategies considerably less often. Thus, they stated that they use mostly the following ways: I think about how I can solve problems the best way; I learn from my own experiences; I accept reality of such situations; I ask people with similar experiences what they would do in such situations.

Most emphasized are strategies referring to problem solving, accepting reality and learning from experience (Picture 2).

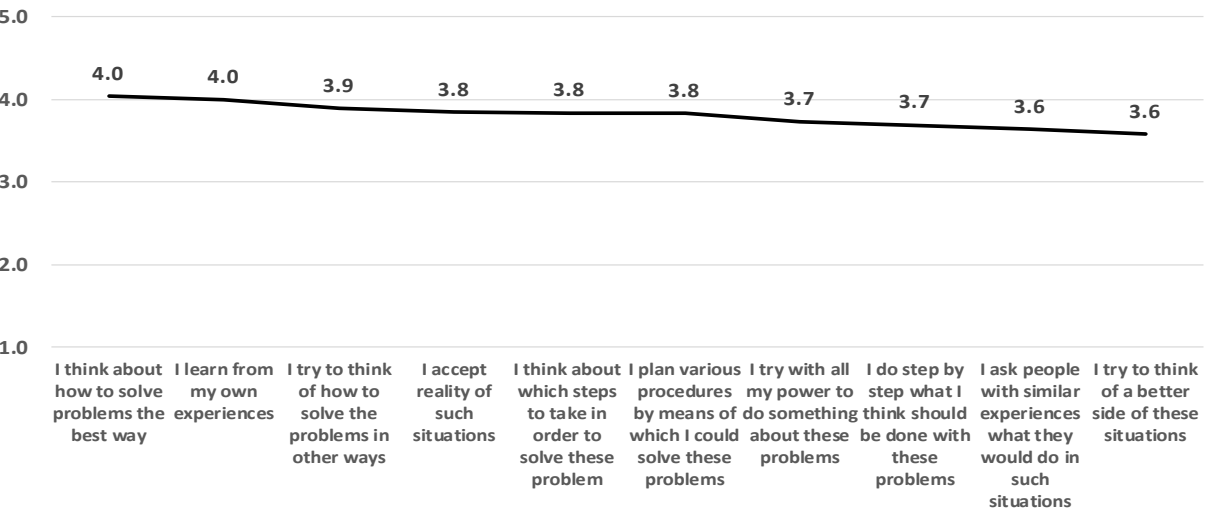

Picture 2 Graphic illustration of coping strategies with stress 


\section{Testing the differences according to gender of the respondents}

Since we had a sufficient number of respondents of both genders in the research, we tested differences in responses concerning particular statements and on satisfaction factors by using the t-test. It was shown that male and female respondents in the research significantly differ in terms of statistics in some sources of stress, elements of coping with stress and job satisfaction.

The differences in sources of stress in women and men showed that women experience the following statements as stressors more often than men: simultaneous solving of a couple of urgent tasks, too short deadlines for solving particular tasks, inappropriate behaviour of school-boys and girls, participation in competitions, neglecting other people's opinion and substitution of male/female colleagues in school. On the other hand, men experience preparation for teaching periods as a greater source of stress in comparison to women.

4

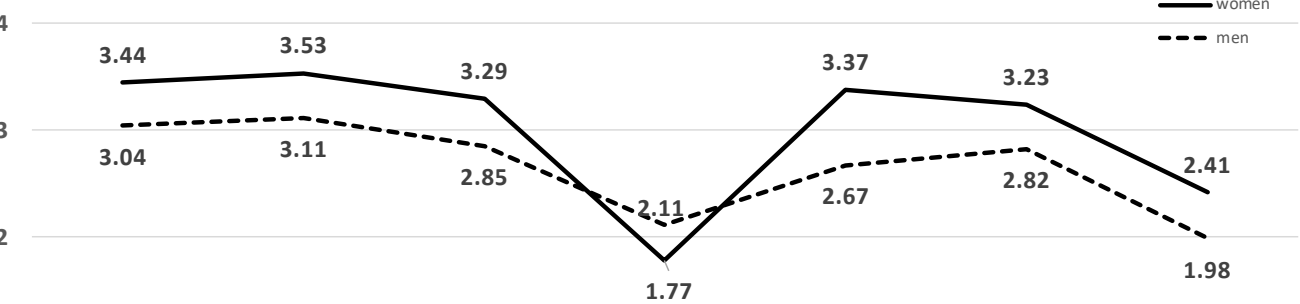

1

\begin{tabular}{|c|c|c|c|c|c|c|}
\hline $\begin{array}{l}\text { Simultaneous } \\
\text { olving of a couple } \\
\text { of urgent tasks } \\
(\mathrm{t}=-2.07, \mathrm{p}<0.05)\end{array}$ & $\begin{array}{l}\text { Too short deadlines } \\
\text { for solving } \\
\text { particular tasks } \\
(t=-2.27 ; p<0.05)\end{array}$ & $\begin{array}{c}\text { Inappropriate } \\
\text { behaviour of } \\
\text { schoolboys/girls } \\
(\mathrm{t}=-2.02 ; \mathrm{p}<0.05)\end{array}$ & $\begin{array}{l}\text { Preparation for } \\
\text { teaching periods } \\
(\mathrm{t}=2.11, \mathrm{p}<0.05)\end{array}$ & $\begin{array}{l}\text { Participation in } \\
\text { competitions } \\
(t=-3.29 ; p<0.01)\end{array}$ & $\begin{array}{l}\text { Disrespect of other } \\
\text { people`s opinion } \\
(t=-2.09 ; p<0.05)\end{array}$ & $\begin{array}{c}\text { Substitution of } \\
\text { male/female } \\
\text { colleagues at } \\
\text { school } \\
(t=-2.20 ; p<0.05)\end{array}$ \\
\hline
\end{tabular}

Picture 3 Graphic illustration of perception of stress sources depending upon the gender of the respondents

Connected with coping strategies, differences according to gender show that in coping with stress women use the following strategies more often: they talk to somebody about their feelings, they try to get emotional support from friends and relatives, they ask people with similar experiences what they would do in such situations, it is hard for them and they show it clearly and they talk with some people about the way they feel concerning men. On the other hand, men turn to finding humour in stressful situations, and they do some physical activities more intensively. 
5

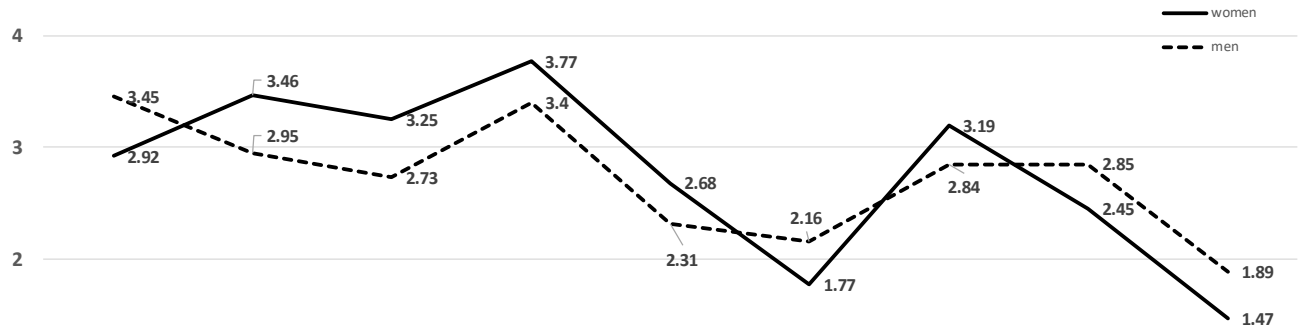

1

\begin{tabular}{|c|c|c|c|c|c|c|c|}
\hline $\begin{array}{l}\text { I try to find } \\
\text { funny side of } \\
\text { these situations } \\
(\mathrm{t}=2.62 ; \mathrm{p}<0.01)\end{array}$ & $\begin{array}{c}\text { I talk to } \\
\text { somebody about } \\
\text { my feelings } \\
(t=-2.65 ; p<0.01)\end{array}$ & $\begin{array}{l}\text { I try to get } \\
\text { emotional } \\
\text { support from } \\
\text { friends and } \\
\text { relatives } \\
\text { (t=-2.77; } p<0.01\end{array}$ & $\begin{array}{l}\text { I ask people with It is hard for me } \\
\text { similar and I show it } \\
\text { experience what clearly } \\
\text { they would do in }(t=-2.11 ; p<0.05) \\
\text { such situations } \\
\text { 1) }(t=-2.30 ; p<0.05)\end{array}$ & $\begin{array}{l}\text { I make fun of } \\
\text { these situations } \\
(t=2.19 ; p<0.05)\end{array}$ & $\begin{array}{c}\text { I talk to some } \\
\text { s people about the } \\
\text { way I feel } \\
(t=-2.01 ; p<0.05)\end{array}$ & $\begin{array}{l}\text { I do some } \\
\text { physical } \\
\text { activities more } \\
\text { intensively } \\
(t=2.16 ; p<0.05)\end{array}$ & $\begin{array}{l}\text { I smoke more } \\
\text { than usually in } \\
\text { order to calm } \\
\text { down } \\
(t=2.08 ; p<0.05)\end{array}$ \\
\hline
\end{tabular}

Picture 4 Graphic illustration of differences in coping with stress depending upon the gender of the respondents

In Job satisfaction we observe that women agree with the following statements more: Work offers me satisfaction and Work gives me the feeling of fulfilment and more positively evaluate their colleagues in relation to men. On the other hand, in relation to women, men agree more with the statements My colleagues are languid and My job is tiring.

5

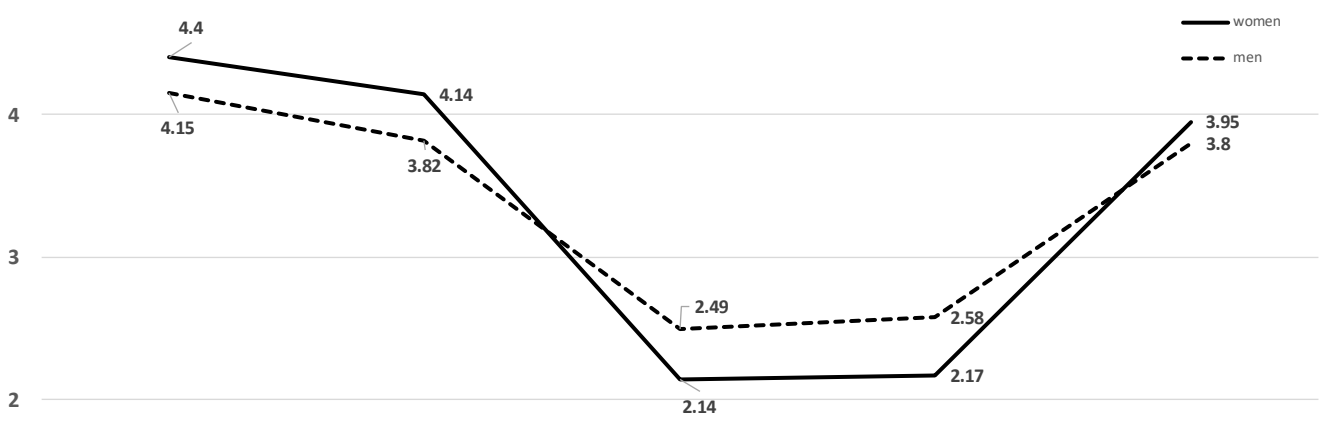

$\begin{array}{ccccc}\begin{array}{c}\text { Work gives me satisfaction } \\ (t=-2.13 ; p<0.05)\end{array} & \begin{array}{c}\text { Work offers me a feeling of } \\ \text { ful-filment }(t=-2.07 ; p<0.05)\end{array} & \begin{array}{c}\text { My colleagues are languid } \\ (t=2.00 ; p<0.05)\end{array} & \begin{array}{c}\text { My work is tiring } \\ (t=2.12 ; p<0.05)\end{array} & \begin{array}{c}\text { Factor colleagues } \\ (t=-1.99 ; p<0.01)\end{array}\end{array}$

Picture 5 Graphic illustration of job satisfaction depending upon the gender of respondents

\section{Testing the differences according to the field of art}

We were also interested in responses to particular statements and satisfaction factors depending upon the type of art field. Results of the t-test showed that male teachers 
in music and dancing schools significantly differ in terms of statistics in the sources of stress, coping strategies with stress and job satisfaction.

Differences in the sources of stress showed that teachers in music schools when compared to the teachers in dancing schools more often state the following as stressors: organization of work schedule at the beginning of school year, too much work at the end of school year, unrealistic expectations of parents, lack of parents' interest, work in groups, pedagogical documentation, lack of appropriate pedagogical measures and inappropriate curriculum. For teachers in dancing schools sources of stress are inappropriate work conditions, which is not characteristic for teachers in music schools.

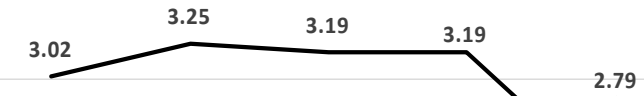

2.67

2.67

2.67

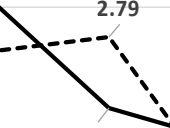

2.29

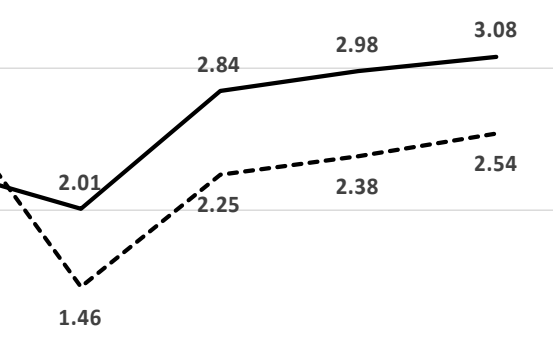

Picture 6 Graphic illustration -difference concerning perception of sources of stress depending upon the teacher's field of work

Differences in relation to coping strategies with stress were shown in the following strategies: I try to use such situations as valuable life experiences $(\mathrm{t}=-2.05 ; \mathrm{p}<.01)$ and $I$ try to relax so I have a drink or a sedative $(\mathrm{t}=3.23 ; \mathrm{p}<.01)$. It is also important to mention that music teachers in relation to dancing teachers more often use ways of relaxation so they have a drink or take a sedative (1.46>1.13), whereas dancing teachers more often than music teachers stated that they try to use such situations as valuable life experiences $(3.92>3.47)$.

In job satisfaction there are differences only in the statement My head-master/headmistress is hard to please $(\mathrm{t}=2.33 ; \mathrm{p}<.05)$ and work factor $(-2.09 ; \mathrm{p}<.05)$. After analysis of arithmetic means we observe that teachers in music schools agree more with the statement My head-master/head-mistress is hard to please $(1.67>1.33)$ in relation to dancing teachers, whereas on the other hand dancing teachers evaluate their work as more positive than music teachers $(4.32>4.04)$. 


\section{Connection of coping with stress and sources of stress with complete satisfaction}

We also wanted to determine whether overall job satisfaction is connected with sources of stress and ways of coping with stress. Despite the fact that the primary goal was prediction of satisfaction on the basis of stress sources and manner of coping with stress, because of the impossibility of implementing the factor analysis and reduction of statements by obtaining a smaller number of factors, it was necessary to calculate correlations of overall satisfaction with each individual statement. Correlations are shown in Table 3.

Table 3

Correlations of emphasized individual sources of stress and coping with stress and overall job satisfaction (only statistically significant correlations are arranged according to the size)

\begin{tabular}{|c|c|c|}
\hline FIELD & STATEMENT & r \\
\hline \multirow{25}{*}{$\begin{array}{l}\text { STRESSFUL } \\
\text { EVENTS }\end{array}$} & Impossibility of appropriate promotion in accordance with work. & $-.384^{* *}$ \\
\hline & Interpersonal relationships in school. & $-.374^{* *}$ \\
\hline & Collaboration with male/female colleagues. & $-.352^{* *}$ \\
\hline & Negative social attitude towards educational teachers' work. & $-.308^{* *}$ \\
\hline & Social status position. & $-.300^{* *}$ \\
\hline & Work with demanding pupils. & $-.300^{* *}$ \\
\hline & Material status. & $-.288^{* *}$ \\
\hline & Substitutions for male/female colleagues in school. & $-.274^{* *}$ \\
\hline & Administrative tasks. & $-.249^{* *}$ \\
\hline & Work in split work shift. & $-.248^{* *}$ \\
\hline & Work in groups. & $-.247^{* *}$ \\
\hline & Time work organization. & $-.245^{* *}$ \\
\hline & Overtime teaching periods. & $-.239^{* *}$ \\
\hline & Too short deadlines for solving particular tasks. & $-.214^{* *}$ \\
\hline & Work with unmotivated pupils. & $-.207^{*}$ \\
\hline & Interruption of teaching period due to some external conditions. & $-.197^{*}$ \\
\hline & Annual examinations. & $-.192^{*}$ \\
\hline & Lack of appropriate pedagogical measures. & $-.191^{*}$ \\
\hline & Preparations for teaching periods. & $-.190^{*}$ \\
\hline & Pedagogical documentation. & $-.182^{*}$ \\
\hline & Misunderstanding of school head-master/mistress. & $-.181^{*}$ \\
\hline & Unrealistic parental expectations. & $-.179^{*}$ \\
\hline & Non-preparation of school-boys/girls for tuition. & $-.179^{*}$ \\
\hline & Work after school week. & $-.178^{*}$ \\
\hline & Tidiness of premises in school. & $-.166^{*}$ \\
\hline
\end{tabular}




\begin{tabular}{|c|c|c|}
\hline FIELD & STATEMENT & $r$ \\
\hline \multirow{16}{*}{$\begin{array}{l}\text { COPING } \\
\text { WITH } \\
\text { STRESS }\end{array}$} & I learn from these experiences. & $.286^{* *}$ \\
\hline & I do not react too impulsively in order not to make problems worse. & $.221^{* *}$ \\
\hline & I accept reality of such situations. & $.178^{*}$ \\
\hline & I think about which steps to take so as to solve these problems. & $.172^{*}$ \\
\hline & I think about how to solve these problems the best way. & $.163^{*}$ \\
\hline & I pretend to be safe and calm. & $-.232^{* *}$ \\
\hline & I simply give up an attempt to achieve my goals. & $-.230^{* *}$ \\
\hline & $\begin{array}{l}\text { I try not to be disturbed by thoughts and activities that are not } \\
\text { connected with these situations. }\end{array}$ & $-.229^{* *}$ \\
\hline & I suppress my feelings. & $-.224^{* *}$ \\
\hline & I withdraw into myself. & $-.197^{*}$ \\
\hline & I pretend as if nothing had happened. & $-.187^{*}$ \\
\hline & I do nothing till the situation allows this. & $-.186^{*}$ \\
\hline & I pretend as if this meant nothing to me. & $-.186^{*}$ \\
\hline & I try less and less to solve these problems. & $-.179 *$ \\
\hline & I avoid company and talks in order to think about the problem. & $-.179^{*}$ \\
\hline & I ask for somebody's sympathy and understanding. & $-.167^{*}$ \\
\hline
\end{tabular}

Correlations in Table 3 show that emphasized various stressors are negatively connected with job satisfaction. In other words, with the increase of emphasis of particular stressors, job satisfaction is decreased. The most emphasized negative correlation with satisfaction is connected with the promotion factor (Impossibility of appropriate promotion in accordance with work), then with factor colleagues (Interpersonal relations and Collaboration with male/female colleagues), social and material status (Negative social attitude towards teachers' educational work, social status position and material status) and more demanding pupils (Work with demanding pupils).

In strategies of coping with stress the most emphasized negative correlation with job satisfaction is observable in the usage of strategies of problem evasion (I pretend to feel safe and calm, I simply give up any attempt to achieve my goals, I suppress my feelings and I pretend as if nothing had happened). In other words, with the increase of problem evasion strategy in coping with stress job satisfaction decreases. On the other hand, there is a positive correlation with job satisfaction and learning from a particular situation (I learn from these situations) and strategies directed to problem solving (I do not react too impulsively in order not to make the problems even worse, I think about which steps to take in order to solve these problems and I think about how to solve these problems in the best way). If teachers start to use coping strategies with stress that are directed towards the problem more, job satisfaction is increased.

\section{Discussion and Conclusions}

Art education is achieved within the system of regular education which implicitly includes music, dancing and art education. Most researches on art field are correlated 
with the expert part of particular art segments. Fields of the researched topics connected with researches of teachers from psychological aspect are not frequent ones. Art education is an essential segment of educational system and is achieved within regular system in accordance with particular curricula. Such type of art education has been researched, therefore, the goal of this research was to realise cognitions about teachers dealing with music and dancing education, since dealing with art, that is, art education of learners is different from regular pupils' education. As a result of the above-mentioned, the goal was to determine sources of stress in teachers in music and dancing schools. Researches on people dealing with art and sport showed general satisfaction and the aim was to realise if this refers to teachers of art fields and the way they cope with work stress and if they are satisfied with their work.

Greatest sources of stress in teachers were: inappropriate behaviour of pupils, too many administrative tasks, disrespect and inappropriate work conditions (Brkić \& Rijavec, 2011; Kokkinos, 2007; Miljković \& Rijavec, 2007; Sklaalvik \& Sklaalvik, 2015).

Greatest sources of stress in piano teachers are interpersonal relations at school (Franceschi \& Reić Ercegovac, 2017).

It should be emphasized that the most important sources of stress for music and dancing teachers are lack of motivation by pupils and parents, various types of disrespect and time-limitation. The results may be interpreted with the fact that art education is not obligatory and therefore it is with good reason one of the more important sources of stress for unmotivated pupils in music and dancing schools.

Stressors that were proved as significant in teachers at music schools in relation to teachers in dancing schools are connected with work organization, parents' disrespect and too much pedagogical documentation, whereas teachers in dancing schools experience inappropriate work conditions as a greater source of stress in relation to teachers in music schools. Teachers in dancing schools need adequate work conditions because of particularity of their work.

The most important coping strategies with stress that are used by teachers in music and dancing schools come from the category of positive strategies and refer to problem solving, accepting the reality and learning from experience. Dancing teachers use these situations more often than music teachers as valuable life experiences. The results are partially in line with the research of teachers in regular schools (Kyiracou, 2001) according to which teachers mostly cope with stress in such a way that they evade conflicts, use various forms of relaxation, solve problems, discuss about the problem with others.

Teachers in music and dancing schools are satisfied with their work although they are least satisfied with their salary. In job satisfaction it is observable that dancing teachers assess their work more positively than music teachers. The obtained results are in accordance with past researches on teachers' satisfaction (Franceschi \& Reić Ercegovac, 2017; Miklec, 2010; Sklaalvik \& Sklaalvik, 2015; Vidić, 2009). The greatest dissatisfaction factor of teachers at work is connected with finances, which can 
partially be connected with the obtained result that teachers are least satisfied with their finances (Kadum et al., 2016). Bakker (2005) found out in the research on music teachers that the greatest sources of job satisfaction are independence at work and collaboration with colleagues.

This research confirmed research was confirmed that female teachers more often use coping strategies with stress by looking for social and emotional support of other people, as it was also in the research by Nasser-Abu Alhija (2015), whereas male teachers showed that one of the ways in which they cope with stress was finding humouristic aspect of the situation in which they find themselves. The greatest source of stress for male teachers is preparation for instruction, whereas for female teachers it is inappropriate behaviour of pupils and too much work at the same time. Differences according to gender in life satisfaction variable revealed that female teachers find greater job satisfaction in the fact that their work contributes to the feeling of fulfilment. Male teachers consider experiencing work as tiresome more than their female colleagues.

Stressors are expectedly negatively correlated with job satisfaction, among which the most emphasized is correlation with the impossibility of appropriate promotion and then with interpersonal relations, social and material status of teachers and work with pupils.

The most emphasized negative correlation of job satisfaction and coping strategies with stress is connected with negative coping strategies. Teachers that cope with stress by using coping strategies directed towards emotions in such a way that they give up an attempt of achieving their goals or pretend as if nothing had happened or feign to be calm, are less satisfied with their work.

However, a positive correlation of job satisfaction and coping strategies directed towards problem solving, which is confirmed by past researches, was observed (Brkić \& Rijavec, 2011). Teachers who solve stressful situations by using strategies of thinking about the best way of solving the problem as well as learning from past situations are more satisfied with their work.

Recommendations for future research of the topic would be to increase the respondent sample in order to carry out a factor analysis of the data that would empower obtaining factors for the Scale of coping with stress and questionnaire Sources of stress. Such procedure would yield a more precise analysis and the possibility of forming a predictive model of job satisfaction of teachers in art schools on the basis of intensity of sources of stress and used coping strategies with stress.

Researches on teachers in primary art schools and teachers in high art schools are welcome as valuable cognitions about art professions as a special and interesting model in the educational system. 


\section{References}

Bahtijarević-Šiber, F. (1999). Management ljudskih potencijala. Golden marketing.

Bakker, A. B. (2005). Flow among music teachers and their students: The cross over of peak experiences. Journal of Vocational Behavior, 66 (1), 26-44. https://doi.org/10.1016/j. jvb.2003.11.001

Betoret, F. D. (2009). Self-efficacy, school resources, job stressors and burnout among Spanish primary and secundary school teachers: a structural equation approach. Educational Psychology, 29 (1), 45-68. https://doi.org/10.1080/01443410802459234

Borg, M. G., \& Riding, R. J. (1991). Occupational Stress and Job Satsisfaction in Teaching. Britisch Educational Journal, 17, 263-281. https://doi.org/10.1080/0141192910170306

Brkić. I., \& Rijavec, M. (2011). Izvori stresa, suočavanje sa stresom i životno zadovoljstvo učitelja razredne i predmetne nastave. Napredak, 152 (2), 211-225.

Carver, C. S., Scheier, M. F., \& Weintraub, J. K. (1989). Assessing coping strategies: A theoretically based approach. Journal of Personality and Social Psychology, 56 (2), 267-283. https://doi. org/10.1037/0022-3514.56.2.267

Chan, D. W. (1988). Stress, Coping Strategies and Psycological Distress among Secundary School Teachers in Hong Kong. American Educational Research Journal, 35, 145-163. https:// doi.org/10.3102/00028312035001145

Dinham, S., \& Scott, C. (1998). A three domain model of teacher and school executive career satsfaction. Journal of Educational Administration, 36 (4), 362-378. https://doi. org/10.1108/09578239810211545

Evers, W. J., Brouwers, A., \& Tomić, W. (2002). Burnout and self-efficacy: A study on teachers beliefs when implemementing an innovative educational system in the Netherlands. British Journal of Educational Psychology, 72 (2), 227-243. https://doi.org/10.1348/000709902158865

Folkman, S., \& Lazarus, R. S. (1990). Coping and emotion. In N. L. Stein, B. Leventhal, \& T. Trabasso (Eds.), Psychological and biological approaches to emotion (pp. 313-332). Lawrence Erlbaum Associates, Inc.

Franceschi, I., \& Reić Ercegovac, I. (2017). Zadovoljstvo poslom, kompetentnost i izvori stresa kod nastavnika klavira. Tonovi-časopis glazbenih i plesnih pedagoga, 32, 1, 84-93.

Gordon, D. (2000). Sources of stress for the Public School Music Teacher: For Case Studies. Contributions to Music Education, 27 (1), 27-40. https://www.jstor.org/stable/24127016

Grant, A. (2007). Relational Job Design and the Motivation to Make a Prosocial Difference. Academy of Managment Review, 32 (2), 393-417. https://doi.org/10.5465/amr.2007.24351328

Gregson, T. (1991). The Separate Construct of Communication Satisfaction and Job Satisfaction. Educational and Psychological Measurement, 51, 39-48. https://doi. org/10.1177/0013164491511003

Hakanen, J. J., Bakker, A. B., \& Schaufeli, W. B. (2006). Burnout and work engagement among teachers. Journal of School Psychology, 43 (6), 495-513. https://doi.org/10.1016/j. jsp.2005.11.001

Hudek-Knežević, J., Kardum, I., \&. Vukmirović, Ž. (1999). The structure of coping styles: A comparative study of Croatian sample. European Journal of Personality 13 (2), 149-161. https://doi.org/10.1002/(SICI)1099-0984(199903/04)13:2<149::AID-PER326>3.0.CO;2-Z 
Jepson, E., \& Forrest, S. (2006). Individual Contributory Factors in Teacher Stress: The Role of Achievemenet Striving and Occupational Commitment. Britisch Journal of Educational Psychology, 76 (1), 183-197. https://doi.org/10.1348/000709905X37299

Kadum, V., Vidaković, S., \& Vranaković, K. (2007). Gledišta učitelja o svojem statusu, motivaciji i Hrvatskom nacionalnom standardu. Napredak, 148 (2), 192-209.

Klassen, R., Perry, N. E., \& Frenzel, A. C. (2012). Teachers Relatedness With Students: An Underemphasized Component of Teachers Basic Psychological Needs. Journal of Educational Psychology 104 (1), 150-165. https://doi.org/10.1037/a0026253

Kokkinos, C. M. (2007). Job stressors, personality and burnout in primary school teachers. British of Educational Psychology, 77 (1), 229-243. https://doi.org/10.1348/000709905X90344

Koludrović, M., Jukić, T., \& Reić Ergovac, I. (2009). Sagorijevanje na poslu kod učitelja razredne i predmetne nastave te srednjoškolskih nastavnika. Život $i$ škola, 22, 235-249.

Kyriacou, C. (2001). Teachers stress: Directions for future Research. Educational Review, 53 (1), 27-35. https://doi.org/10.1080/00131910120033628

Lazarus, R. S., \& Folkman, S. (1984). Stress, appraisal, and coping. Springer.

Lazarus, R.S., \& Folkman, S. (2004). Stres procjena i suočavanje. Naklada Slap.

Locke, E. A. (1976). The nature and causes of job satisfaction. U: M. D. Dunnette, Handbook of Industrial and Organizational Psychology (pp. 1297-1349). Rand McNally.

Maslach, C. (2003). Job burnout: New directions in research and intervention. Current Directions in Psychology Science, 12 (5), 182-192. htts://doi.org/10.1111/1467-8721.01258

Miklec, D. (2010). Školsko ozračje, zadovoljstvo poslom i sudjelovanje u odlučivanju učitelja osnovne škole. (Magistarski rad). Zagreb: Učiteljski fakultet.

Miljković, D., \& Rijavec, M. (2007). What makes teachers happy? Quantitative and qualitative aspects of job satisfaction and psychological well-being of teachers. In M. Cindrić (Ed.), Pedagogija u kontektstu društva znanja (pp. 41-47) Zagreb: Učiteljski fakultet, Sveučilište u Zagrebu.

Montgomery, C., \& Rupp, A. (2005). A Meta-analysis foe Exploring the Diverse Causes and Effects of Stress in Teachers. Canadian Journal of Education, 28 (3), 458-486. https://doi. org/10.2307/4126479

Nasser-Abu Alhija, F. (2015). Teacher Stress and Coping: The Role of Personal and Job Characteristics. Social and Behavior Science 185, 374-380. https://doi.org/10.1016/j. $\underline{\text { sbspro.2015.03.415 }}$

Pillay, H., Goddard, R., \& Wills, L. (2005). Well-being, burnout and competence: Implications for teachers. Australian Journal of Teacher Education, 30 (2), 22-33. https://doi.org/10.14221/ ajte.2005v30n2.3

Skaalvik, E. M., \& Skaalvik, S. (2009). Does school context matter? Relations with teacher burnout and job satisfaction. Teaching and Teacher Education, 25 (3), 518-524. https://doi. org/10.1016/j.tate.2008.12.006

Sklaalvik, E. M., \& Sklaalvik, S. (2011). Teacher job satisfaction and motivation to leave the teaching profession: Reations with school context, feeling of belonging, and emotional exhaustion. Teaching and Teacher Education 27 (6), 1029-1038. https://doi.org/10.1016/j. tate.2011.04.001 
Skaalvik, E. M., \& Skaalvik, S. (2014). Teacher Self-Efficacy and Perceived Autonomy: Relations with Teacher Engagement, Job Satisfaction, and Emotional Exhaustion. Psychological Reports, 114, 68-77. https://doi.org/10.2466/14.02.PR0.114k14w0

Sklaalvik, E. M., \& Sklaalvik, S. (2015). Job Satisfaction, Stress and Coping Strategies in the Teaching Profession-What Do Teachers Say? International Education Studies, 8 (3), 181192. https://doi.org/10.5539/ies.v8n3p181

Smit, P., Kendall, L., \& Hulin, C. (1969). The mesarement of satisfaction in work and retrement. Rand Mc Nally.

Timms, C., Graham, D., \& Cottrell, D. (2007). I just want to teach: Queensland independent school teachers and their workload. Journal of Educational Administration, 45 (5), 596-586. https://doi.org/10.1108/09578230710778204

Vidić, T. (2009). Zadovoljstvo poslom učitelja u osnovnoj školi. Napredak 150 (1), 7-20.

Zurlo, M. C., Pes, D., \& Cooper, C. L. (2007). Stress in teaching: a study of occupational stress and its determinants among Italian schoolteachers. Stress and Health, 23 (4), 231241. https://doi.org/10.1002/smi.1141

\author{
Melita Ivanković \\ Ministry of Science and Education \\ of the Republic of Croatia \\ Donje svetice 38 \\ 10000 Zagreb, Croatia \\ melitaivankovic8@gmail.com
}




\section{Izvori stresa, strategije suočavanja sa stresom i zadovoljstvo poslom učitelja u umjetničkim školama}

\section{Sažetak}

Istraživanja o učiteljskom stresu pokazala su da je stres važan čimbenik o kojem ovisi odgojno-obrazovni proces (Kyriacou, 2001). U ovom radu istraživani su učitelji u umjetničkim školama u Republici Hrvatskoj $(N=148)$. Cilj je ovoga rada utvrditi koji su izvori stresa kod učitelja u osnovnim glazbenim i plesnim školama. Također, jedan od problema je uočiti i načine suočavanja učitelja sa stresom, kao i povezanost sa zadovoljstvom posla učitelja u umjetničkim školama. Učitelji u umjetničkim školama uglavnom su zadovoljni svojim poslom unatoč tome što je to vrlo stresno zanimanje. Izvori stresa učitelja u umjetničkim školama u nekoj mjeri su slični izvorima stresa dosadašnjih istraživanja učitelja. Učitelji se većinom koriste strategijama upravljanja stresom usmjerenim na problem, kao što je rješavanje problema. Također je uočena pozitivna povezanost pozitivnih strategija upravljanja stresom i zadovoljstva poslom, a najvišu povezanost pokazuje korištenje pozitivnih strategija suočavanja sa stresom. Potvrdena je negativna korelacija strategija usmjerenih na emocije i zadovoljstva poslom, kao što je izbjegavanje suočavanja s problemom. Rezultati upućuju na posebnosti umjetničkog obrazovanja te daju poticaj za daljnja istraživanja.

Ključne riječi: izvori stresa; strategije suočavanja; učitelji umjetničkih područja; zadovoljstvo poslom. 